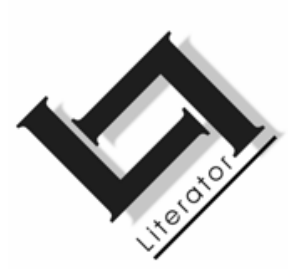

\title{
The role of political songs in the realisation of democracy in South Africa
}

\author{
H.C. Groenewald \\ Department of African Languages \\ University of Johannesburg \\ AUCKLAND PARK \\ E-mail: hcgr@lw.rau.ac.za
}

\section{Abstract}

The role of political songs in the realisation of democracy in South Africa

The issue this article attempts to explore is whether a form of oral art - political songs - played a part in achieving democracy in South Africa, and, if so, how this aim was achieved. In this regard it should be kept in mind that political songs form part of the large, vibrant body of oral art in South Africa. An aspect of oral art that is particularly relevant to political songs is that it is often performed to be efficacious, that is, it is performed to achieve a desired result. Equally important is the attribute of performance. It is obvious that the political song derived much of its power from the dynamics of performance. Political songs evolved from church hymns with obscure references of suffering to power singing with an overt and belligerent political message. The conclusion arrived at is that political songs played a vital role in forging democracy from below.

\section{Opsomming}

Die rol van politieke liedere in die bereiking van demokrasie in Suid-Afrika

Die kwessie wat in hierdie artikel ondersoek word, is of ' $n$ vorm van mondelinge kuns, naamlik politieke liedere, 'n aandeel gehad het in die bereiking van demokrasie in Suid-Afrika, en indien wel, wat daardie aandeel behels het. Dit moet in gedagte gehou word dat politieke liedere een voorbeeld is van die groot en lewenskragtige korpus van mondelinge kuns in Suid-Afrika. 'n Aspek van mondelinge kuns wat besonder toepaslik is op 
politieke liedere is die feit dat sulke liedere dikwels opgevoer word om 'n sekere doelwit te bereik of om 'n verlangde uitkoms te bewerkstellig. Die kenmerke en aard van mondelinge opvoering is egter net so belangrik. Dit is duidelik dat die politieke lied 'n groot deel van sy impak verkry het op grond van die dinamika wat die opvoering daarvan teweeggebring het. Politieke liedere het ontwikkel vanuit kerkliedere met bedekte verwysings na lyding, tot opruiende sang met openlike en strydlustige politieke boodskappe. Die gevolgtrekking word gemaak dat politieke liedere 'n beslissende rol gespeel het om demokrasie van onder af tot stand te bring.

\section{Introduction}

Oral art in South Africa can rightly be seen as "literature from below" in the sense that it is the literary production of ordinary, and, in many cases, unlearned people. Oral art is "literary" in the sense that it avails itself of devices such as functional repetition and imagery. The phrase "from below" also captures the historical position of oral art in illustrating that oral art/ orality precedes literacy. Oral art is by nature performative and often non-fictitious (although fictitious elements and tropes are utilised) in that it is acted out by real people concerned about issues of their daily existence. Sometimes oral art is socially efficacious and is performed (often as ritual) to achieve a desired result. In this article it will be attempted to indicate in which way political songs, as examples of oral art, have been politically efficacious. On other occasions oral art is performed for entertainment. Oral art is by and large ephemeral, in that texts produced in performance last for a short while, never to be performed again. The effect of some texts, on the other hand, may last for a relatively long period before fading away. The performers of oral art are generally from the poorer section of the population. However, despite material poverty, the richness of oral art among the people is astounding. Whether in urban or rural settings, despite prevailing poverty, people engage in performances to invoke divine protection in obeisance to their beliefs, to engage with powers they deem to be exploitive and oppressive, but also to entertain themselves. Since the performing "stage" of oral art is not elevated and set apart from the audience, "actors" and "audience" exchange roles effortlessly during performance(s). The open category of performance thus often includes people of all ages, races, and social standing. Singing remains the most vibrant form of oral art in South Africa.

Although the incidence of outspoken political songs is a relatively recent development in South Africa, there should be no doubt about 
its status as a form of oral art. Like traditional songs, most political songs are short texts composed orally, often within the framework of a performance situation, and sung in a call and response style. Oral art owes its existence to a nurturing context and its effect to performance; the same is true of political songs. Political songs were nurtured in the specific South African context of a lack of equal rights, and, as will be indicated, derived its effect from the performance of these songs.

The issue this article proposes to answer is whether political songs played a major part in achieving democracy, and, if so, how this was achieved.

\section{Theoretical background}

In pre-1994 South Africa, racial ideologies, culminating during National Party rule in the ideology of apartheid, led to numerous repressive laws to enforce an ideology that entrenched inequality. In her book, Forging Democracy from Below, Elisabeth Wood (2000:5) takes the stand that democracy in South Africa came about "by the sustained insurgency of lower-class actors". Emphasising the point she says that "the transition to democracy would not have taken place [...] when it did, as it did, and with the same consequences in the absence of sustained popular mobilisation". Under such a government the economy was not allowed to develop according to free-market forces but was coerced by ideologies that were not economic by nature. In the words of Wood (2000:7): "Extraeconomic coercion thus entails gross violations of fundamental liberal rights of association, speech, free movement, self-ownership, due process, and equality before the law."

\section{Popular mobilisation and oral memory}

During the first three decades after the ANC's coming into being the movement did not direct itself to the masses in its fight for democracy, but sought to get the support of the small black middle class. The ANC's political action consisted of petitions and appeals to the government (Wood, 2000:125). Gradually it became clear to the ANC that it was primarily the poorer section of the population that was suffering most under repressive laws. The full potential of the collective action of the poor and repressed became clear when, in the early 40s, workers staged many bus boycotts in Alexandra Township in protest against rising fares. The result was that bus fare price increases were delayed. Wood (2000:125) notes that in the early 40 s workers staged about sixty strikes against mines and other 
companies. Ten years later, bus boycotts were still evident, for example, in about 1954 bus boycotts erupted in Evaton, a township south of Johannesburg. A song from that time castigated the Italian owners of the bus service and alluded to the disruption resulting from the boycott:

Koloi tsa Motariana

Di entse moferefere

Ba bang ba re di a palangwa

Ba bang ba re ha di palangwe.

[Vehicles of the Italian

Have brought strife

Some say they can be boarded

Others say they dare not be boarded.]

(Groenewald \& Makopo, 1991:85)

The government's suppression of these strikes led the ANC to adopt a militant position and to recognise new leaders such as Nelson Mandela, Oliver Tambo and Walter Sisulu. These leaders founded the ANC Youth League in 1944, resulting in the Youth League's "Programme of Action" in 1949. The Youth League rejected the fundamental policies of the National Party, such as segregation and apartheid, and in 1952 it announced its Defiance Campaign of Civil Disobedience. Wood (2000:127) notes that the government "continued to enforce racial segregation with forced removals of entire communities [...] as in Sophiatown in 1955". A well-known popular song memorialises this event as follows:

$\mathrm{U}$ tla a utlwa makgowa a re a re yeng eMeadowlands

Meadowlands, Meadowlands, ons duck ni ons pola hi.

[You will hear the whites saying let's go to Meadowlands

Meadowlands, Meadowlands, we are not leaving, we are staying here.]

Various resistance organisations, including the ANC, adopted the Freedom Charter in 1955, resulting in increased harassment by the government. Leaders were banned from holding meetings and many were tried for treason, only to be found not guilty in 1961. A song that memorialises the Freedom Charter goes as follows: (The parts in italics are the calls of the lead singer, or lead singers; the other parts are the group's responses.)

Emazweni

Bakhala ngani? lyobakhala ngani? $\quad 4 \mathrm{x}$

lyo bakhala ngani? $\quad 4 \mathrm{x}$ 
IFreedom Charter

Bakhala ngayo emazweni

[In the countries

What are they crying about?

The Freedom Charter

They are crying about it in the countries lyo bakhala ngani? $\quad 4 \mathrm{x}$

lyo bakhala ngani?

$4 \mathrm{x}$

lyo what are they crying about?

lyo what are they crying about?

lyo what are they crying about?

lyo what are they

crying about?]

(From: South African Freedom Songs, [2001])

In 1959 the "Africanists" broke away from the ANC to form the PAC because they did not agree with the ANC's policy of non-racialism. Consequently, resistance was organised by competing groups. This period between the late 50 s to early 60 s was characterised by protests against the pass laws. The PAC organised various marches, one of which was of course the march to the local police station in Sharpeville on 21 March 1960 when 69 people were killed by police and 180 wounded. In 1956 twenty thousand women marched to government offices in Pretoria. The slogan "Wathint' abafazi, wathint' imbokodo" (Touch the women and you touch a stone) immortalised the women's resolve at this time.

In the 60s the government tried to repress resistance campaigns through numerous banning orders. In reaction to this and to criticism by radical groups, ANC policies took a fundamental shift toward armed resistance. In June 1961 Umkhonto Wesizwe (Spear of the Nation) was formed under the leadership of Nelson Mandela. Many acts of sabotage were carried out - about 200 in the early 60 s - but most were minor incidents "with no substantial effect" (Wood, 2000:130) and "they never posed a real threat to the security of the state" (Wood, 2000:132). Government's reaction, which devastated the ANC leadership, was to send Nelson Mandela and many other top leaders to Robben Island following the Rivonia Treason Trial, while many others fled the country. Although the top structure of the ANC had been crippled by the government, the people were still mobilising and singing about their leaders and Umkhonto Wesizwe the many songs about the top leaders and about MK testify to this. One song about Madiba goes as follows:

Nelson Mandela

He says freedom now

Mandela says away with slavery

In our land of Africa
Nelson Mandela says fight for freedom

Mandela says freedom now

Mandela says away with slavery

In our land of Africa 
Rholihlahla Mandela

Freedom is in your hands

Show us now the way to freedom

In our land of Africa
Rholihlahla Mandela

Freedom is in your hands

Show us now the way to freedom

In our land of Africa.

(From: South African Freedom Songs, [2001])

Despite the fact that the leaders of the ANC had been imprisoned by the government, civil disobedience and strikes erupted again in the 70 s, reaching a peak in 1987, at which time "more than 11 percent of nonagricultural workers struck" (Wood, 2000:138). Widespread unrest followed the Soweto uprising of 16 June 1976. In the late 70 s and early 80s many trade unions emerged and their membership grew dramatically, and with this growth came increased worker militancy. At the same time the ANC increased its guerrilla attacks 228 attacks in 1986 alone (Wood, 2000:139) - resulting in the government's 1986 declaration of a state of emergency.

Apart from repression, the government thought it could counteract unrest by introducing reforms, all to no avail. Ultimately, both the business sector and the government came to realise that there would be no end to civil unrest without an acceptable political settlement. These groups realised that it would be necessary to recognise "the ANC as the insurgent counter-elite necessary for negotiations to resolve the crisis confronting the country" (Wood, 2000:181). The following song, dating back to 80 s, calls for the release of Nelson Mandela:

Oliva Tambo Oliva Tambo thetha noBotha akhulul' uMadiba $2 x$

UMandel' uzobusa Akhulul' uMadiba.

$4 x$

Oliver Tambo Oliver Tambo speak to Botha so that he can release Madiba

Mandela will rule so that he can release Madiba.

$2 x$

$4 x$

Essentially then it was the uprising of the oppressed masses that led to democracy. In my view, this uprising derived its power from, among other things, the performance of political songs.

\section{Performance: creating a liberating space}

Mobilisation, a political term implying mass action, does not provide the details of how a group achieves its goal. The concept of performance is helpful in this respect to particularise aspects of mobilisation. A performance is constituted when the following aspects are in place: context (macro socio-/cultural/political circumstances - as described in sections 2 and 3 ), situation (or 
event, such as a wedding, funeral, march, etcetera, as illustrated in section 6), performer(s), text and audience. Performance thus implies that circumstances prompt a group to stage an event, as it were, where performers will voice a text of some nature. A successful performance also presupposes a certain common resolve and commitment. Performances of political songs vividly show the measure of resolve and cohesion of a group(s), as well as the measure of energy needed in order for performances to be effective. Quoting Bell with reference to ritualisation, Van Vuuren (2003:69) speaks of people in performance as a "unified corporate body". A group without a text does, however, not have much power. Political songs are undoubtedly the fuel of performance in a political context. A formidable synergy of individuals is created when a group sings the same song and performs the same body movements. While individuals work for the effectiveness of the group, the group in turn empowers every individual.

It is interesting to note that although mobilisation may imply a huge number of performers, the optimal performing group of political songs is a relatively small group. Even in huge crowds, political songs are performed by smaller groups within the crowd. Political songs are examples of communal oral art in the sense that a political song is always sung by a group. Thus, although a particular song was originally conceptualised or composed by a gifted individual, authorship is not rigorously claimed, and the right to perform is taken for granted by others. In performance, a spirited caller who is able to shout out above the drone, who chooses popular songs and leads them enthusiastically, is a valuable asset. Every marcher in a crowd has the right to call out a song, but less vociferous callers lead a song only for a short while. Performance then, implies the unified, communal efforts of composer, caller, responders and audience in a particular context and event. The communal aspect of performance, and of African culture in general, does have a latent sinister side: individual aberrance is not tolerated. This has been seen all too often - and not only in the struggle years - where non-performers risk their lives for not being one with the group.

Political singing in the face of the adversary is normally performed at high volume since it is the collective volume of voices that gives the singing its sting. Desmond Tutu (in South African Freedom Songs) remarked: "It scared the living daylight out of [...] the enemy out there. Whenever they heard [...] it then it sent shivers down their spine." 
The performance space of some forms of oral art in South Africa is a liberating space in that it cuts across gender and age barriers and allows men and women and even children to perform in the same space. This is particularly true of political songs. Political performance also cuts through ethnic and race lines, provided that performers share a common political resolve. Political songs are sung regionally in the particular African languages of that region, but Zulu remains the dominant language. In South Africa during the period of apartheid the performance arena was the church, the street, the school grounds, the university campus, the work place, the cemetery, the stadium. While these spaces are still used, the performance of political songs has also invaded former apartheid strongholds, such as the grounds of the Union Buildings and Parliament.

While the performance of political songs is a liberating act, it is captivating, both in the enjoyment of singing and in the ideology of the words being sung. Even today, the joy of performance/singing is so captivating that suspect ideologies are not questioned. Clearly, there is no reason at present to incite people to leave the country and take up arms, to mention one theme, yet songs proclaiming such themes are still enjoyed.

\section{The evolution of political songs}

The history of South Africa yearning for liberation goes as far back as the 17th century when slaves served Dutch masters at the Cape of Good Hope. In the immense field of the discourse of freedom, the discussion will be restricted to some aspects of the evolution of political songs in the apartheid and post-apartheid periods.

The first phase encompassed the composition and adaptation of church songs, going back to 1897 when Enoch Sontonga composed the first stanza of "Nkosi sikelela i-Afrika", surely the most famous of all political songs. The oblique political reference contained in the request "Nkosi sikelela i-Afrika" indicated that all was not well in Africa. In some political songs originating in the church there is no overt political layer, in fact, the word layer of one song ironically endorses a status quo, for example in the words of the song "Makube njalo kuthe kube kunaphakade" ("May it be so until eternity" - From: South African Freedom Songs). In this respect one must infer that another layer of unsung words is present in the minds of the singers, which indicates that context also gives political meaning to a song. 
By the late 1950s racial discrimination had intensified, and church songs were adapted in a much more forthright way, as exemplified in the following song which originally spoke of believers' resolve to follow Jesus:

Somlandela, somlandel' uThuli, Luthuli

Somlandela yonke indawo Somlandela

Somlandela, somlandel' uThuli Luthuli

Lapho aya khona somlandela Somlandela

Bhek' ijele Bhek' ijel' igcwel' uyalandela Bhek' ijele $\quad$ x3

Lapho aya khona somlandela Somlandela

[We will follow him, we will follow Uthuli, Luthuli

We will follow him all over We will follow him

We will follow him, we will follow Uthuli Luthuli

Wherever he goes we will follow We will follow him

Look at the jail Look at the jail, it's full, you will follow

Look at the jail

Wherever he goes we will follow We will follow him]

(From: South African Freedom Songs)

As passive resistance officially gave way to the armed struggle in 1961 when Umkhonto Wesizwe (Spear of the Nation) was formed, this new direction in the struggle added a new fierceness to songs. New weapons (as expressed in the words umshini (machine), scorpion, and bazooka, the (racial) identity of the enemy and the consequences of an armed struggle were clearly worded in songs. A prime example is the MK (Umkhonto Wesizwe) song:

Hamba Hamba kahle Mkhonto Mkhonto we-Mkhonto, Mkhonto Wesizwe 2x

Thina Thin' abant' boMkhonto sizimisele ukuwabulala wona amabhunu. $\quad 2 x$

[Go Go well Mkhonto Mkhonto you Mkhonto, Mkhonto Wesizwe

$2 x$

We We the people of Mkhonto we are determined to kill the Boers.] 2x

(From: South African Freedom Songs)

The severe clampdown of the apartheid government on resistance groups that led to the Rivonia trial and imprisonment of the ANC leadership, also led to the first wave of refugees. The second wave was the youth who fled in the wake of the crack down of the Soweto uprising of 1976. Many of these people ended up in training camps 
in other African countries. While being trained in combat and terrorist activities, they also learned new songs. According to John Matshikiza (South African Freedom Songs) the youths who came to the training camps brought a new urgency and dynamic to these camps and sang new kinds of songs, songs which did not have their origin in the church, but in the yards and on the streets of Soweto. While some political songs would provide traditional songs (such as wedding songs) with new content, others would be original political songs. The toyi-toyi song (or chant) with its militant style of singing and dancing was a totally new kind of song. Ronnie Kasrils (South African Freedom Songs) called it a "parade ground drill" and, according to Lucie Pagé (South African Freedom Songs), it had its origins in Zimbabwe, except for "that bark" (Pallo Jordan, South African Freedom Songs) which, according to Jordan, originated in training camps in North African states such as Algeria and Morocco. According to Kasrils (South African Freedom Songs) the toyi-toyi song had a powerful influence on the struggle of the 1980s.

The current period in the history of political songs, that is, the period since 1994, does not differ markedly from the pre-1994 period as regards political themes. Many of the songs sang before 1994 still exist today, with one fundamental difference: these songs are now also sung in celebration of freedom and commitment to change. However, it should be noted that there is still occasion for protest, as the next section will show.

\section{Election year is still far off: protest before celebration}

Far less amicability is lavished on political leaders when elections lie in the distant future. Between elections politicians are viewed more critically when making public statements. During COSATU's antiprivatisation strike on 29 and 30 August 2001, cabinet ministers and other leaders involved in the government's privatisation drive were criticised contemptuously for proceeding with the privatisation of certain state-owned companies. The following song speaks for itself in its expression of the singers' disgust about the issue of privatisation:

Radebe, Radebe, Radebe

Ngamasimba le nt' oyenzayo

Hee thula, thula' thula

Ngamasimba le nt' oyenzayo

Geraldine, Geraldine, Geraldine

Bubufebe le nt' oyenzayo
[What you are doing is shit Hey, quiet, quiet, quiet What you are doing is shit

What you are doing is fornication 
Hee thula, thula, thula Bubufebe le nt' oyenzayo.
Hey quiet, quiet, quiet What you are doing is fornication.]

(See Sikwebu [2001:13]. Jeff Radebe was Minister of Public Enterprises at the time and Geraldine Frazer-Moleketi Minister of Public Administration.)

In the absence of election fever not even the President is immune to criticism. During the same strike Gauteng Premier Bhazima Shilowa and President Thabo Mbeki were criticised for their approval of privatisation:

Shilowa awuyaz' into oyifunayo (3x)

Sikunikil' isandla

Sakunika nengalo

Sakunika amabele

Awuyaz' into oyifunayo

Mbeki awuyaz' into oyifunayo (3x)

Sakuthath' ehlathini

Sakunika ivoti

Sakufak' epalamende

Awuyaz' into oyifunayo.
[Shilowa, you don't know what you want We gave you the hand

We even gave you the arm

We gave you the breasts You don't know what you want

[Mbeki, you don't know what you want We took you from the bush

We gave you the vote We put you in parliament You don't know what you want.]

Eleven months later, at the South African Communist Party Congress held from 24 to 28 July 2002, delegates again had reason to be angry, this time when President Thabo Mbeki declined to address the Congress. Delegates sang belligerently "Makuliwe uMbeki akafuni sithethathethane" - Let's fight, Mbeki does not want to talk (Martorell, 2002:1).

One of the beacons of the new democracy in South Africa was the inception of the Constitutional Court, the final and ultimate recourse to justice in the country. In 2004 the Court commemorated its first 10 years of existence while its new buildings were inaugurated in Braamfontein, Johannesburg during a ceremony on 21 March. Knowing that it would have a unique opportunity to protest in President Mbeki's presence (and in the presence of the 11 judges of 
the Court), the Anti-Privatisation Forum staged a march to the Constitutional Court in protest against the government's plans to privatise certain state assets. Needless to say, the march was prevented by the police as it was declared an illegal march.

The examples mentioned above, and many others, such as the songs of the TAC (Treatment Action Campaign; see the CD Jikelele: Global Treatment, 2001), which have been protesting against the government's stance on HIVIAIDS, demonstrate that the spirit of protest is latent in many interest groups and easily flares up when an opportunity presents itself.

\section{Memories, publicity, protest and celebration}

It can hardly be said that political songs sung in the run-up to the 2004 general election were sung in protest. On the contrary, most of the singing performed during this time was done in celebration of the victory of the ANC at the polls in 1994 and in commemoration of the struggle. Songs were also sung to publicise particular political parties. Such was certainly the case when NNP canvassers performed a toyi-toyi song to canvass in Westbury, a predominantly Coloured area west of Johannesburg, on 26 March 2004.

Most of the songs recorded by me at the ANC's Siyanqoba rally, held on 4 April 2004 at the FNB Stadium, and at the 10th anniversary of democracy at the Union Buildings in Pretoria on 27 April 2004, were pre-1994 struggle songs. A vast repertoire of songs was built up in the memories of the masses, memories that would not be softened after only 10 years of freedom; and such memories had no need to be softened, because for the singers the spirit of umzabalazo, the spirit of resistance, is in itself a value that cannot be surrendered quickly, if at all. Not surprisingly then, the songs celebrating resistance featured several times at these venues. A well-known version goes as follows:

Umzabalazo uyasivumela Umzabalazo uyasivumela (repeated a few times)

Le nale Umzabalazo uyasivumela (repeated a few times)

Yonk' indawo Umzabalazo uyasivumela. (repeated a few times)

[Resistance responds for us Resistance responds for us Here and there Resistance responds for us All over Resistance responds for us]

(Own recording) 
The notion of resistance went hand in hand with the means of resistance. The taking up of arms was a frequent topic at the venues mentioned above. In this regard there were topics of incitement to set the country on fire (whether physically or by encouraging to protest), of leaving the country and of taking up arms. The first topic is referred to obliquely when singers sing "Ndiza moya Kuyabanda" (Blow wind It is cold). The following song tells the story familiar to many comrades, of leaving the country and taking up arms:

Ubofik' ekhaya ubatshele Fik' ekhaya ubatshele

La ushiye khona La ushiye khona

Ibhazuka lbhazuka khona ehlathini

Ase-Angola Ase-Angola

Thatha nas' iskopiyon Nas' iskopiyon

Shay' ulale Shay' ulale

Zonke le zinja Zonke le zinja

Zamabhunu Zamabhunu

Ungasiyekele Bamb' isandla sam' Oliva Tambo Bamb' isandla sam'.

(The lines of the song are repeated in various ways.)

[You must go home and tell them Go home and tell them

Where you left (it) Where you left (it)

The bazooka The bazooka in the bush

Of Angola Of Angola

Take this scorpion This scorpion

Strike and lie down Strike and lie down

All these dogs All these dogs

The Boers Of the Boers

Don't leave us Take my hand Oliver Tambo Take my hand.)

(Own recording)

The reference to "the Boers" brings one to the most frequently referred to groups of people - coming second only to political leaders - in the songs recorded at the two venues. Judging from these references, "the Boers" have seared the memories of the singers indelibly. A song sung by different groups recalls not only the frightful assassination of Chris Hani, but, even more forcibly, the arrogance of "the Boers" in imagining that the people could forgive this act:

Ayangcangcazela Ayangcangcazela amaBhun' abulala Chris Hani, ayangcangcazela

Uth' asixole kanjani? Uth' sixole kanjani amabhun' abulala

Chris Hani, sizoxola kanjani? 
[They are trembling They are trembling (with fear) the Boers who killed Chris Hani, they are trembling

How do you think must we forgive? How do you think must we forgive the Boers who killed Chris Hani, how will we forgive?]

(Own recording)

Some songs carry the much publicised notion of killing the Boers; for instance, one song declares "Thina as'khathali masibulal' amaBhunu" (We don't tire of killing the Boers - own recording). It should be noted that, though singing such a song with the enthusiasm that invariably accompanies the performance of political songs, singers may apologise afterwards saying "Don't take it seriously!", as happened at the Siyanqoba rally (own recording). Clearly, the performance of a political song locks the singers into the ideology of the song, simply because the act of performance is captivating.

Singing as a form of living oral art demonstrates the capability of rising to new occasions. New songs (i.e. sung since 1994) encourage people to vote (sung at the Siyanqoba rally - own recording), to become volunteers, refer to the fact that women are becoming famous, or announce that the ANC is carrying out its duties. In the latter case, a version of a song has a possible double meaning: while the singers say they are being worked for, the words of the song may have the sweet, ironic meaning that now the tables have been turned and whites are working for blacks. The version sang at the Union Buildings was a mixture of Ndebele (or Zulu) and Southern Sotho:

Hayayayaya siyasebeletswa. (repeated in various ways)

[Hayayayaya we are being worked for.]

(Own recording)

In the new South Africa it is apparent that there still are many political issues calling for public protest - from seemingly trivial matters affecting only a handful of people, to matters of grave concern affecting the country as a whole. For example, during the Siyanqoba rally on 4 April 2004, a group of between 15 and 20 young men protested that they had not received T-shirts, while thousands of other attendees had received black or yellow T-shirts. On their way to the stadium the men who had not received T-shirts, took off their old shirts, threw them on the ground and danced around them singing the following simple song with great 
resentment: "Sifun' iskipa (6x) skipa, skipa" (We want a T-shirt own recording).

The dreaded weapon of organised labour - strikes - remains a feature of the labour landscape. The university campus will also be a battle ground for educational issues. Recently a student wrote in a letter (The Star, 23/6/2004): "campuses will be turned into protest and toyi-toyi grounds if student funding is not addressed". Public health, especially the issue of HIVIAIDS, will also remain contentious for the foreseeable future.

The prime occasion for celebration by all citizens was no doubt the 10 years of democracy celebrations at the Union Buildings. People expressed their gratitude for freedom by celebrating their own culture. Groups of people representing Xhosa, Pedi, and sangoma culture sang their songs. The singing of scathing political songs at this venue must be seen as the ultimate expression of victory, and when sung in Afrikaans, it can hardly be more poignant, as illustrated in the following song:

Toyi toyi Toyi toyi.

[Toyi toyi Ons Pretoria toe] (repeated)

(Own recording)

"Going to Pretoria" as the songs says, refers to Pretoria as a destination for celebration. It was of course a way of saying "we are going to take the seat of government".

\section{Conclusion}

In the struggle for freedom, oral art has earned itself a place as a very able comrade. As stated, political songs "pulled us together, energized us" (Baleka Mbete, South African Freedom Songs). Desmond Tutu in turn says, "Without these freedom songs, our struggle would have been a great deal longer, a great deal bloodier, and perhaps not even successful" (South African Freedom Songs). Political songs can rightly be seen as a most effective form of performance to enforce democracy from below, as Ronnie Kasrils (South African Freedom Songs) points out:

In South Africa we did not defeat apartheid by out shooting it [...] song and toyi-toyi featured as a weapon. This is what inspired people, it inflamed people and was very much part of this massive avalanche that, in the end, buried apartheid, so it was a real weapon in a concrete sense.

Such is the power of the "literature from below". 


\section{List of references}

GROENEWALD, H.C. \& MAKOPO, S.A. 1991. The political song: tradition and innovation for liberation. (In Sienaert, E., Lewis, M. \& Bell, N., eds. Oral tradition and innovation: new wine in old bottles? Durban: University of Natal Oral Documentation and Research Centre. p. 76-103.)

MARTORELL, J. 2002. South African Communist Party Congress. Rank and file on the offensive against the Right Wing. http://www.marxist.com/ Africa/sacp_congress_rank_and_file.html Date of access: 4 June 2004.

SIKWEBU, D. 2001. The strike hit parade. SA Labour Bulletin, 25(6):13-16.

SOUTH AFRICAN FREEDOM SONGS. 2001. University of the Western Cape: Mayibuye Centre. [CD].

THE STAR. 23/6/2004.

VAN VUUREN, C.J. 2003. Singing against the grinding stone: the Ndebele and Imbokodo during the unrest of 1986-1988. Southern African Journal for Folklore Studies, 13(2):59-72.

WOOD, E.J. 2000. Forging democracy from below. Cambridge: Cambridge University Press.

\section{Key concepts:}

democracy

oral art

performance

political songs

\section{Kernbegrippe:}

demokrasie

mondelinge kuns

opvoering

politieke liedere 